University of Michigan Law School University of Michigan Law School Scholarship Repository

1991

\title{
Of Outlaws, Christians, Horsemeat, and Writing: Uniform Laws and Saga Iceland
}

William I. Miller

University of Michigan Law School, wimiller@umich.edu

Available at: https://repository.law.umich.edu/articles/205

Follow this and additional works at: https://repository.law.umich.edu/articles

Part of the Comparative and Foreign Law Commons, Legal History Commons, $\underline{\text { Religion Law }}$ Commons, and the Rule of Law Commons

\section{Recommended Citation}

Miller, William I. "Of Outlaws, Christians, Horsemeat, and Writing: Uniform Laws and Saga Iceland." Mich. L. Rev. 89 (1991): 2081-95.

This Symposium is brought to you for free and open access by the Faculty Scholarship at University of Michigan Law School Scholarship Repository. It has been accepted for inclusion in Articles by an authorized administrator of University of Michigan Law School Scholarship Repository. For more information, please contact mlaw.repository@umich.edu. 


\title{
OF OUTLAWS, CHRISTIANS, HORSEMEAT, AND WRITING: UNIFORM LAWS AND SAGA ICELAND
}

\author{
William Ian Miller*
}

Our word law is a loanword from Old Norse. ${ }^{1}$ It makes its earliest appearances in Old English manuscripts in the late tenth century. At that time the Old English word for law was, believe it or not, æ, written as a digraph called "ash." Now most readers, myself included, tend to experience anxiety when we confront a ligatured vowel like $æ$ and so we untie it as a prelude to getting rid of it altogether: we turn an ssthete $^{2}$ into an aesthete before finally humiliating him (or her) as an esthete, all to resolve our nervousness. King Ethelred the Unready becomes AEthelred before turning ignominiously into Ethelred. If $æ$ had stayed our word for law and we make the necessary allowances for what happened to the pronunciation of Old English words that had an ash in them, instead of lawyers we would simply be "ers," which indeed was how Chaucer spelled arse. ${ }^{3}$ And imagine how hard it would be to maintain the pompous tone in which we are wont to speak of THE LAW if instead we were speaking of THE E, pronounced with

* Professor of Law, University of Michigan. B.A. 1969, Wisconsin; M.Phil. 1973, Ph.D. 1975, J.D. 1980 Yale. - Ed. The author wishes to thank Robert Bartlett, Kathleen Koehler, and Larry Kramer for comment and criticism.

1. See OXFord English DictionaRY s.v. law, sb.1. (2d ed. 1989) [hereinafter OED]. The late Old English form of the Old Norse form was lagu. The subsequent history of the sound indicated by the $g$, a dorsal voiced fricative, when proceeded by a short $a$ was for the consonant to become vocalized leading to the diphthongization and lengthening of the preceding vowel. Thus Old English laga became law, and Old English maga became maw (stomach). This footnote is actually a desperate attempt on my part to put to use some of the Anglo-Saxon philology that occupied a good portion of my time in graduate school some 20 years ago.

2. The $æ$ in cesthete is clearly not an Anglo-Saxon ash. It had already disappeared in English in the thirteenth century. The ligatured $\mathfrak{z}$ was reintroduced in the sixteenth century in forms derived from Latinized Greek words. See OED, s.v. æ.

3. E.g., G. Chaucer, The Canterbury TAles: The Miller's Tale, lines $3798-807$ (F. Robinson 2d ed. 1957):

This Nicholas was risen for to pisse,

And thoughte he wolde amenden al the jape;

He sholde kisse his ers er that he scape.

And up the wyndowe dide he hastily,

And out his ers he putteth pryvely

Over the buttok, to the haunche-bon;

And therwith spak this clerk, this Absolon,

"Spek, swete bryd. I noot nat wher thou art."

This Nicholas anoon leet fle a fart,

As greet as it had been a thonder-dent... 
a short $e$ to add even further indignity to the institution. So we have something to thank those Vikings for after all. They might have emptied England of most of its silver and carried off no small number of captives as slaves, but they left us our word for the model of order ${ }^{4}-$ law - as an exchange for the disorders they wrought.

So the etymology of law gives me my warrant for the violent yoking of my title: uniform laws and saga Iceland. And the retirement of my colleague Bill Pierce gives me the occasion for yoking them. The sagas were written in Old Norse or, more precisely, in a dialect of Old Norse philologists call Old Icelandic. Old Norse lög, a plural form, had a literal sense of things that had been laid down. But the word referred to more than positive enactments - i.e., laws; it also indicated the community that shared those laws, a community that was then known as "our law."s Hence the term outlaw' to indicate someone who had been expelled from the community and who as an outlaw was shorn of all jural status and all jural rights: he or she was supposed to be killed by anyone hearty enough to undertake the task. ${ }^{7}$ "Law" even came to be thought of as the land in which those people who followed one particular law dwelled. Hence the name Danelaw for the east midland region of England where the bulk of the invading Viking armies settled.

Given this conception of law as the community defined by a single body of laws, there could not be, by definition, a persistent problem about uniformity of laws. Local custom might vary, but if it varied too much we were in a different world, a world of their law, not our law. With this as a most superficial of backdrops let me give you two case studies. The first deals with the conversion of Iceland to Christianity in the year 1000 . This particular case treats of the specific problem of what happens when one faction within the unity of "our law"

4. They also left us the word "berserk." Old Norse berserkr, i.e, bear shirt, bear sark, refers to a certain class of wild warriors in the style of Malay amoks or even the contrary warriors of the plains Indians. Berserks, to credit the sagas, were prized as shock troops but rather a pain to deal with in times of peace.

5. See K. Hastrup, Culture and History in Medieval Iceland: AN ANTHRopoLOGICAL ANALYSIS OF STRUCTURE AND CHANGE 207 (1985).

6. In Old Icelandic the word for outlaw was skogarmatr, literally meaning a man of the woods, that is, a metaphorical wolf. Norwegian law, however, used a reflex of "outlaw" (útlagi) for outlaw. Each term indicates beyond the pale, outside the law, one doing it literally, the other metaphorically.

7. The "she" is not just a concession to nonsexist language. The old Icelandic laws indicate that women were punishable in the same way men were for the same offenses. The sagas, however, show no women outlaws even though they do show women engaging in activities that would have supported an outlawry action against them. For a fuller discussion of this and many other matters raised in this Article, see generally W. MILLER, BLOODTAKING AND PEACEMAKING: FEUD, LAW, AND SOCIETY IN SAGA ICELAND (1990). 
threatens to secede and make their own law. The second case discusses the problem for uniformity of law and laws when an oral culture meets a powerful new technology we call writing.

\section{The Law of Heathens, the Law of Christians}

Surely the greatest gift that Christianity brought to the Icelanders was writing. Christianity, like the Jewish religion it had broken from, was a text-based religion. Writing lay at its foundation and writing was one of the means that enabled it to spread so successfully at the expense of pagan cults, which, being local, oral, and without the belief that truth was universal, single, and uniform, were simply no match for Christianity's universalizing pretensions and administrative sophistication, which itself was largely enabled by writing. ${ }^{8}$

But writing enabled the Icelanders too. It gave them the means to talk about themselves and their past in new ways and in such ways that we can hear them to this day. Indeed, the first text written in Icelandic contains the story of how Iceland became Christian. The entire account occupies barely four pages. We know that it was written by a man named Ari Thorgilsson ${ }^{9}$ sometime in the third or fourth decades of the twelfth century, that is, some 130 years after the events took place. Ari was quite scrupulous about his sources and he says he got his story from a man named Teit, his foster father, who in turn got it from an eyewitness. ${ }^{10}$ Ari himself, when young, also talked to at least one person who could remember events in the year $1000 .{ }^{11}$

The key events are these. King Olaf Tryggvason of Norway made it his goal to convert the Icelanders. To this end he sent a priest named Thangbrand out to Iceland to preach the new faith. Another source informs us that Thangbrand was a rather tough customer. ${ }^{12}$ He once bought a slave girl in Ireland and then killed a man in Denmark who challenged him for her. He supported the church that Olaf granted him in Norway by raiding. ${ }^{13}$ And when he asked as a penance for his raiding that Olaf assign him some thankless task, Olaf told him (1986).

8. See generally J. GOODY, THE LOGIC OF WRITING AND THE ORGANIZATION OF SOCIETY

9. Except in citations and for actual references to Old Icelandic words I have normalized Old Icelandic names. $\mathrm{b}$ (thorn) and $\delta$ (eth) are thus rended as th and $d$ respectively. Accented vowels appear unaccented.

10. Ari Porgilsson, Íslendingabók, ch. 7, in 1 ÍsLENZK FORNRT 1 (Jakob Benediktsson ed. 1968).

11. Id. at ch. 9.

12. See Kristni saga, chs. 5-7, in 1 BISKUPA SöGUR 1 (1858).

13. Individual churches required an endowment in order to be sustained. Thangbrand funds his church with capital of dubious origin. 
to go to Iceland and try to convert the Icelanders. Thangbrand succeeded in baptizing some people in the year or two he stayed in Iceland. And he also succeeded, according to Ari, in killing "two or three men who had slandered him."14 It seems that Iceland was getting too hot for Thangbrand's tastes (one source says he was outlawed for one of his killings) and he headed back to Norway to report to King Olaf that he thought the Christian cause in Iceland was hopeless. Olaf responded by taking hostage the Icelanders who were in Norway and threatening to maim or kill them. Some of these hostages were connected to the leading families in Iceland and this led two prominent Icelanders - named Gizurr and Hjalti - to take responsibility for promoting the Christian cause.

There are three more dramatis personae to introduce: the first, a man named Thorgeir who was the Lawspeaker in the year 1000; the second, a rock called the Law Rock; and the third, an assembly called the Allthing. Every midsummer, in a place called Thingvellir or Thingplains, the Allthing was held. A thing ${ }^{15}$ was a meeting and the Allthing was a thing for all of Iceland. At it were held the courts at which litigants pursued their claims. ${ }^{16}$ In a prominent place on the thing grounds stood the Law Rock. It was there that the Lawspeaker recited the body of law. In a preliterate and oral culture he was the society's statute book. Each summer he was to declaim from memory one third of the corpus of laws. If the surviving laws dating from the twelfth and thirteenth centuries are any indication of the size of the body of law in the year 1000 , then Thorgeir would have had nearly 700 pages of densely printed rules and regulations packed away in his head. ${ }^{17}$ The Lawspeaker also had the duty to inform anyone who

14. See Ari Borgilsson, supra note 10. Old Norse slander usually involved accusing someone of being the "passive" partner in homosexual couplings. See, eg., Kristni saga, supra note 12, at ch. 4.

15. For what it is worth, it is interesting to consider the rich legal life of the word "thing" in the Romance and Germanic languages. Cognates of English thing appear in the early Germanic languages in the sense of meeting for judicial purposes, affair, suit, matter. Compare also our "cause" of action from Latin causa, which yielded French chose and Italian cosa, ie., thing. Also, Latin res has the sense of "case" in law in addition to "thing." The OED s.v. thing, sb.1 invites us to compare German Sache, meaning thing, whose root sense meant strife or dispute. See the semantic history of the cognate English word sake. OED s.v. sake sb. It seems that the original sense of "thing" was ultimately "a matter in dispute," which then became generalized to indicate any matter. The parallel development of causa in the romance languages hardly indicates a universal sense that law and contention create the universe of matter, but it provides the material for fruitless musings and good stories.

16. The courts were held in the open. Cases were heard by a panel of 36 judges. For a full discussion, see W. MILLER, supra note 7, at 16-22.

17. Id. at 43-44. The early Icelandic laws are collectively known as Grágás. The laws are remarkable for their rich casuistic style and the range of matters they purport to regulate. For more background on them, see id. at $43-44,221-57$. 
asked him what the law was. He was elected to a three-year term and was reimbursed with a claim on half the fines levied in certain claims at the Allthing. The Lawspeaker, the only paid officeholder in the Icelandic polity, the Law Rock, and the Allthing were also, importantly, symbols of the unity of the community's legal culture. ${ }^{18}$

Now let us return to Gizurr and Hjalti, the leaders of the Christian faction, as they enter the thing grounds. And please bear with me as I quote Ari's description of what ensued:

[Gizurr and Hjalti] rode to the thing, accompanied by their kinsmen and friends who met them before as they had been requested. The heathens arrayed themselves fully armed and they were on the brink of battle. The next day Gizurr and Hjalti went to the Law Rock and stated their case. And it is said that it was extraordinary how well they spoke. And the result of that was that one man after another named witnesses, Christians and heathens, and declared themselves each to be "out of law" with the other, after which they left the Law Rock. Then the Christians asked Hall of Sida to be their Lawspeaker and to proclaim the law that they should follow. But Hall got himself out of it by making a deal with Thorgeir the Lawspeaker that he should proclaim the laws; Thorgeir, however, was still a heathen at the time. And afterward, when people returned to their booths, ${ }^{19}$ Thorgeir lay down, stretched his cloak over himself and lay there the whole day and next night without speaking a word. The following morning he got up and sent word that everyone should go to the Law Rock. When people gathered he began to speak: he said that it seemed to him that things were in a dreadful state if people did not all have one law in this land; he set forth in various ways why they should not let this happen, that it would lead to discord, and that it was a reasonable expectation that armed conflicts would arise among men such that the land would be wasted. . . . "I think it advisable," he said, "that we do not let those have their way who are most confrontational; let us so compromise the case between them that each side gets something out of their case. And let us all have one law and one faith. There can be no doubt that if we sunder the law, we also destroy the peace."

He so concluded his speech that both sides agreed to accept the unified law that he would proclaim. It was then prescribed in the law that everyone should be Christian and those in this land who had not already been baptized should undergo baptism. But the old law governing infanticide and the eating of horsemeat would stand. People could sacrifice to the old gods secretly if they wanted to, but they were to be liable for

18. Id. at $18-19,226-28$.

19. During the two weeks of the Allthing people lived in turf booths. See id. at 221-57. 
lesser outlawry ${ }^{20}$ if witnesses ${ }^{21}$ were present ${ }^{22} \ldots$. .

Now I suppose that it is not hard for us, even committed pluralists, to see the merits of Thorgeir's position, but other things here probably jar the nonmedievalists among us. How is it that horsemeat figures on a level of importance with infanticide, or with sacrificing to the old gods? What could the Icelanders' notion of Christianity have been if they were willing to compromise on which God or gods one could pray to, but not on the formalities of baptism? Why in the world did the newly chosen Lawspeaker for the Christian faction, Hall, trust the fortunes of his cause to the pagan Thorgeir? And just what in the world was Thorgeir doing lying under his cloak for so long?

Let me offer a few quick and hence inadequate solutions to some of these interesting issues raised by Ari's text. Our sources do not give us enough information to reconstruct the practice of infanticide, but we might hazard a few comments: Infanticide probably functioned as a form of postpartem birth control. The sources contain little hints that people felt the land was near the limits of its carrying capacity. An extra mouth could doom the viability of a farm and a few extra could doom even a district. ${ }^{23}$ Many heads of households also had slaves and they surely did not want to give up the right to control the size of the slave population.

But what do we do with horsemeat? There is some evidence that horses were an important staple in the diet of the poor and that horsemeat was simply a standard form of animal protein which people may have liked to eat for its own sake. ${ }^{24}$ But that would hardly indicate why it might be feared that a casualty of christianizing would be the loss of this source of food. Horses, it seems, figured prominently in Germanic fertility cults and this alone might be all that we need to

20. Lesser outlawry meant banishment from Iceland for three years and confiscation of property. It was distinguished from full outlawry, which obliged the person getting the defendant outlawed to kill his outlaw and also privileged anyone else to do the killing. Anyone protecting or aiding an outlaw was liable for lesser outlawry. There was also a form of mitigated full outlawry which allowed the outlaw passage abroad.

21. Proof in Icelandic legal actions was generally made by a verdict of a jury of neighbors who may or may not have actually been witnesses to the events in issue. Proof also could be made by witness testimony. Here it appears that Thorgeir is requiring the stricter form of proof - witnesses - in order to punish "public" pagans.

22. Ari Porgilsson, supra note 10, at ch. 7 (author's translation).

23. See W. MrLLER, supra note 7, at 16; and see especially Clover, The Politics of Scarcity: Notes on the Sex Ratio in Early Scandinavia, 60 Scandinavian Stud. 147-88 (1988).

24. See 2 Óláfs Saga Tryggvasonar en Mesta 196-97 (Ólafur Halldórsson ed. 1961):

But those people who most opposed Christianity could hardly imagine raising all the children born, both to the rich and poor, considering the ban and prohibition as acceptable food those things which before were the chief sustenance of the populace. For this reason they were to have their way on this point: the old laws should stand regarding exposing children and eating horsemeat. (author's translation). 
explain the Icelanders' general concern that the new religion might seek to prevent the eating of horses. We see synods in England in the eighth century, for example, legislating on precisely this matter. ${ }^{25}$ Thorgeir's explicit reference to eating horses might simply have been another way of restating the proposition that he was serious about allowing people to continue to sacrifice to the gods in private.

Later sources, either preserving additional information that Ari suppressed or simply supplying new information to give more reason to Ari's account, say that Hall paid Thorgeir to proclaim the law and that it was risky to do so given that Thorgeir was a heathen. ${ }^{26}$ Yet even if we accept that Hall bribed Thorgeir, it still shows, somewhat ironically, how deeply committed Hall was to the old legitimate order. Thorgeir, not Hall, was the properly elected Lawspeaker, and Hall clearly knew it and cared that it was so. The very fact that Hall deferred to Thorgeir's authority shows also that Hall believed it was more important to have one law than to be Christian. And then Thorgeir lay under the cloak. I assume he was making a public and ostentatious display ${ }^{27}$ of something, but of what? One scholar has argued that Thorgeir was in a shamanistic trance seeking the source of the new law. ${ }^{28}$ It might only be that he needed time to compose the new laws he was about to utter. In any event, the display got noticed; the solution he came up with was generally accepted; and it just might be that the probability of its acceptability was enhanced by Thorgeir's strangely ritualized behavior.

One of the more interesting features of the Icelandic conversion is that the chief story the medieval Icelanders told themselves about it was not a story of good beliefs driving out bad, but a story of the success of a unified system of law in which there was enough leeway for astute political actors to maneuver. This is a story less about their

25. See Report of the Legates George and Theophylact of their proceedings in England (787 A.D.), in III CoUNCILS AND ECCLESIASTICAL DOCUMENTS RELATING TO GREAT BRITAIN AND IrELAND 459 (A. Haddan \& W. Stubbs eds. 1871); see also MonUmenta Germaniae Historica, 1 Epistolae Selectae, Die Briefe des Heuligen Bonifatius and Lulius 50 (M. Tangl ed. 1916). But also note that a century earlier Archbishop Theodore observed that eating horses was not prohibited. Theodore's Penitential, XI.4., in III CoUNCILS AND ECCLESIASTICAL Documents RelaTING to Great BRITAIN AND Ireland, supra, at 198. See also J. MCNeill \& Helena M. Gamer, Medieval Handbooks of Penance (1938) 157 (noting "An Old Irish Penitential" I.2, to the effect that "[a]nyone who eats the flesh of a horse, or drinks the blood or urine of an animal, does penance for three years and a half.").

26. Njáls saga, ch. 105, in 12 ÍsLENZK FORNRTT 1 (Einar Ól. Sveinsson ed. 1954); Kristni saga, supra note 12, at ch. 11; 2 ÓLÁs SAGA TRYGGVASONAR EN MESTA, supra note 24, at 191.

27. Was it actually public? It said the people went back to their booths. Did Thorgeir? Booths were not exactly private dwellings in any event. They housed fairly large groups of men.

28. J6N Hinefill Apalstenssson, Under the Cloak: The Acceptance of ChristrANITy IN ICELAND WITH PARTICULAR REFERENCE to the RELIGIOUS AtTTtUdes PREVAIIING AT THE TIME 103-23 (1978). 
law becoming christianized than of Christianity being "led into [their] law," much as a manumitted slave was led into the law. ${ }^{29}$ It is not as if all that many individual laws would have to change, only that new laws formally instituting the new faith would have to be created. The rules regarding pasturing, pledging, summoning, and so on, would stay the same. What would change was the identity of "our law" in the sense of law as a community.

Thorgeir conceived of his decision as an arbitration of a legal dispute brought under the auspices of the old law and old institutions: "let us so compromise the case between them that each side get something out of their case." And like so many legal claims, this one was settled by compromise before the case went to judgment. By conceiving of conversion as a political and legal matter the compromise became, if not quite the desired outcome, an outcome that the norms of legal and political interaction prepared both factions to accept as within the realm of conceivability and acceptability. The compromise preserved the unity of their law and this was specifically articulated by Thorgeir as the best reason for becoming Christian.

The Christians probably felt that they had gotten the better of Thorgeir's judgment. Certainly things turned out to their ultimate advantage, although this probably would have been the case no matter what Thorgeir had decided. If you wanted to think of yourself as connected to European culture you were simply going to have to become Christian sooner or later. Thorgeir adjudged that everyone was to become officially Christian; everyone was to be baptized. But Christian form was not to prevent infanticide, horsemeat, or, incredibly, the private maintenance of family cults and pagan devotions. No one was as yet asking people to pretend to believe what they did not believe. This is a compromise a churchman would not have been able to make with ease publicly, ${ }^{30}$ and it is especially interesting because it shows that a

29. GRÁGÁs Ia 192 (Vilhjálmur Finsen ed. 1852) (reprint 1974). For a translation of this provision see LaWs OF EARLY ICELAND: GRÁgAs 174 (A. Dennis, P. Foote \& R. Perkins trans. 1980).

30. Yet under certain circumstances Christianity could tolerate some juridical and religious pluralism. Christianity's relations with Islam in Spain, for example, were significantly more accommodating than they were with Slavic and Germanic pagan cults. In twelfth-century Toledo, after it had been retaken from the Moslems in 1085, the three main ethnic groups in the city Christian, Moslem, and Mozarabic (Arabic speaking Christians) - were each allowed their own law. Clearly Islam could provide a weighty and sustained opposition to Christianity in a way that local pagan cults could not. See R. BARTLETT, THE DYNAMICS OF EXPANSION IN THE High Middle Ages: Conquest, Colonization and Cultural Change in Europe 9501350 (forthcoming). It was, of course, not at all unusual even well into the high middle ages for law to be personal, that is, for an individual to be governed by the law of his or her ethnic group. So in areas of mixed ethnicity a Slav, for example, would be judged by Slavic law, a German by Germanic law. Nevertheless, by the end of the middle ages we see a diminishing willingmess for any accommodations at all. Id. 
unified law was not meant to mean a unified system of beliefs or a unified system of practices. The decreasing variation in practice and perhaps belief that eventually occurred is another story, one requiring us to delve into the institutional and ideological structure of the Christian church - organized, enduring, jealous, and intrusive - that posed itself against uninstitutionalized private pagan practice - diffuse, nonuniversalist, and unfunded - as well as against liturgical variation within, and institutional defections from, its own ranks. The compromise, in other words, was only possible because these Icelanders, both pagan and Christian, as exemplified by Thorgeir and Hall, were still tolerant in the pagan style. Paganism wore its localism as a badge of honor. And since the Christian God was no less a god to pagans for being Christian, they would be less averse to letting Him get his foot in the door than Christians would be regarding pagan gods. Christians did not deny the existence of pagan gods, they just denied that they were gods instead of devils.

Thorgeir's compromise also articulated for the first time a distinction between public and private practices. The Old Norse world had always made the distinction between innangaros and utangar $\delta s,{ }^{31}$ the world of men, and the world of giants, ${ }^{32}$ or what was inside the fence (garor) and what lay outside of it. But Thorgeir's distinction was a new one, one that looked forward to the one so much legal and political theory is obsessed with. The old distinction was between what was friendly and familiar and what was hostile and strange, between the land of men and the land of giants, between culture and nature; the new one was between a sphere in which the claims of the community were paramount and one into which the community did not intrude.

Robert Cover, in what has become one of the better known law review articles to appear in the last decade, argued that state law is oppressive to the extent that it suppresses the formation of other systems of law among self-identifying groups within the bounds of the state. ${ }^{33}$ Cover finds virtue where Thorgeir found vice. There is no necessary reason why two groups could not coexist within the same boundaries, each affiliated with a different legal community. Practices and rules would develop to handle intergroup disputes. Or would they? This was Iceland, a frontier community that already was beginning to self-identify as a community characterized by its own law. ${ }^{34}$

31. See K. HASTRUP, supra note 5 , at 60.

32. Id. at $142-45$.

33. Cover, The Supreme Court, 1982 Term - Foreword: Nomos and Narrative, 97 HARV. L. ReV. 4 (1983).

34. Cf. Hastrup, Establishing an Ethnicity: The Emergence of the "Icelanders" in the Early 
The people would have had to give up more than just jural unity if the Christian faction had seceded; they would have had to give up their newly acquired identity. And there was no "neutral" central authority or imperial presence that could have arbitrated disputes between the groups independent of feud or war. To this we might add the cultural assumptions regarding someone who was sharing your territory and was not in your law. Such a person was likely to be conceptualized as slave, outlaw, or stranger. Given these cultural categories, how in the world could one build one polity with two laws? The ready answer is that one would need a strong state. But given the weak or nonexistent state apparatus (there was no state beyond the Lawspeaker, the two-week long Allthing, plus local things that met in the spring), the heroic sensibility, the frontier mentality, and the exclusivist pretensions of one of the groups, what you had was a recipe for exactly what Thorgeir supposed: "that it was a reasonable expectation that armed conflicts would arise among men such that the land would be wasted." 35

\section{ONE LAW But MaNy Writings}

Consider what it means to have a large and complex body of law in a stateless society. Not only were there no permanent institutions or bureaucratic structures, but there was no writing. Law was preserved and transmitted by memory and by talk among the class of legal experts from whose ranks the lawspeakers were drawn. These were the people who knew the law where knowing the law meant first remembering it and only then as a secondary matter knowing how to manipulate it and use it in litigation or in other disputing strategies.

Then came writing and, in 1117 , the requirement that the laws should be written. Again our source is Ari: "The first summer of Bergthor's lawspeakership [anno 1117] a new law was made that our laws should be written in a book at Haflidi Masson's during the winter according to the dictation and advice of Haflidi, Bergthor, and other learned men who were appointed to the task."36 Now getting the laws into writing may solve some problems. It seems to impose a lesser burden on people's memories. But it creates new problems, ones that bring us back abruptly to the matter of uniformity in laws. How do we identify the true text of a law when written texts vary? In the preGutenberg era, written texts were produced one at time, each one la-

Middle Ages, in Semantic ANTHRopology $145-60$ (D. Parkin ed. 1982) (the Icelanders emerged as a self-declared ethnic group when the laws of their society were written down).

35. Ari Porgilsson, supra note 10, at ch. 7 (author's translation).

36. See id. at ch. 10. 
boriously copied by scribes who not only made inadvertent "typos," but accidently dropped paragraphs and chapters. Scribes made more than just mechanical errors. They often got very interested in what they were copying and added things they thought should be there, or subtracted things they wished to censor. ${ }^{37}$

But others besides scribes wrote law in Iceland. Icelanders loved law. It was both serious business and great sport. It provided the substance of childhood games and of adult feuds. They studied it and it appears that some people kept their own manuscripts of laws, which may have been faithfully remembered, but then again may have been exercises in writing or proposing legislation or simply may have contained a multitude of lapses of memory. ${ }^{38}$ How, in the absence of a centralized record office or of bureaucratic structures of some stability and permanence, do we make sure written laws do not proliferate at the whim of anyone who has some parchment and some literacy? Within a short time after the laws were first reduced to writing in 1117 (we do not know precisely how long but probably not later than the end of the twelfth century ${ }^{39}$ ), there was need for a citation law to provide some way of ordering the authority of competing variant texts:

It is also prescribed that in this country what is found in books is to be law. And if books differ, then what is found in the books which the bishops own is to be accepted. If their books also differ, then that one is to prevail which says it at greater length in words that affect the case at issue. But if they say it at the same length but each in its own version, then the one which is in Skálholt ${ }^{40}$ is to prevail. Everything in the book which Haflidi had made is to be accepted unless it has since been modified, but only those things from the sayings of other men learned in law which do not contradict it, although everything in them which restores

37. Texts even invited reader and hearer to participate in the transmission and emendation process. Consider the following passage from a thirteenth-century Norwegian text:

This request, however, which surely may be granted to any man, we should like to make: we ask all good men who hear this book to give it careful thought and study; and if there should be aught which seems necessary to the work but has not been included, whether concerning morals and conduct or discreet and proper forms of speech, let them insert it in proper form and connection. And if they find any matters which seem to impair the work or to have been discussed at too great length, let them discreetly remove all such and thus, amending our ignorance in kindness, help our work to be appreciated in proper spirit. For it was not pride that impelled us to labor but good-will toward all who seemed to need and desire knowledge of this sort.

The King's Mirror (Speculum Regale - Konungs Skuggsia) 76 (L. M. Larson trans. 1917). If we can assume that this passage is authorial is it not quite clear just what the author intends. He might be simply suggesting that his hearers or readers should silently supply the necessary changes in their heads and spare the text. But the request seems to call for a real intervention with pen and parchment.

38. See P. Foote, Some Lines in Lögréttupáttr, in AuRvandilstå 155-64 (M. Barnes, H. Bekker-Nielsen \& G. Weber eds. 1984).

39. Id. at 158-59.

40. This was the oldest of Iceland's two episcopal sees. 
things left out or makes things clearer is to be accepted. If people dispute a point of law and the books do not decide it then the Lögrétta ${ }^{41}$ is to be cleared to take up the matter.42

This is really a remarkable enactment. I have discussed it elsewhere ${ }^{43}$ and it has been the subject of at least one very insightful article, ${ }^{44}$ so I limit myself here to a few observations. The law shows already how far written law's prestige and power has surpassed oral law: "what is found in books is to be law." Oral law is still not denied authority, but its existence looks precarious. And if a law wishes to get the benefit of the doubt as to whether or not it is law or will remain law, it had better get itself put to parchment. Now there is no reason to think that variant versions of laws are only a problem of writing. They must have existed in the oral law too. Peoples' memories might differ, among other things, as to the text of a law, as to whether it was properly enacted, as to its continuing validity. But oral law had a way of emending itself. Think how precarious certain rules must have been if they no longer accorded with how things were done, and hence were harder to remember. We have one saga case in which the Lawspeaker expresses admiration for a man's legal skills in a way that shows how thinly certain rules held to their lives: "There are more great legal experts around than I thought. . . . I thought that I was the only person to know this provision now that Njal is dead, because I believe he alone knew this."45 Presumably variants in oral law would have a way of fading away at about the same rate that glitches in memory produced new ones. But written variant versions did not die. They simply multiplied, with new variants giving rise to yet newer ones as scribes miscopied or tampered with already corrupt texts.

The rules ranking the relative authority of the texts look rather strange to the modern eye. Authority is determined first by the status of who owns the book, then by length of the relevant provision, then by location of the particular version, except the original text of the laws is to trump everything unless it has been changed. But the status of Haflidi's original text is doubtful since provisions have been changed. ${ }^{46}$ Moreover, the "sayings of men learned in law," (presuma-

41. The Lögrétta was a body that met at the Allthing. It was made up of 48 men holding the status of chieftain, each of whom chose two advisors from among their followers and the two bishops. It was responsible for making and altering the law. For a discussion, see W. MilıER, supra note 7 , at 18.

42. GRÁGÁs Ia 213, supra note 17. I have borrowed here the translation of Dennis, Foote \& Perkins in LAWS OF EARLY ICELAND: GrÁgás, supra note 29, at 190-91.

43. See W. Miller, supra note 7, at 225-26.

44. See P. Foote, supra note 38.

45. Njáls saga, supra note 26, at ch. 142 (author's translation).

46. It does not appear that the reference is to the original manuscript of Haflidi's text, but to 
bly these are also written, not just oral utterances) ${ }^{47}$ have the status of law in certain circumstances. The generation of law, we see, was hard to constrain. Rules generated comment which became incorporated into the rule. Scribes made errors and legal experts experimented and all of this noise could become authoritative depending on the circumstances. This is all different in one important way from differing interpretations of the same invariant foundational text. Here what was varying was the foundational text. The sayings of men learned in law apparently only had the status of law when these sayings had the look of a law, following its diction, its jargon, and its subject matter - that is, they had to have the look of legitimacy. The last tiebreaker, the last chance to obtain uniformity among variant texts, was finally to send it to the body that formally made new law to remake the law anew and send it out to endure the same process of mutation again.

As we have just seen, lack of uniformity in this world came in two forms: competing systems of law, that is, competing jurisdictional claims on persons, as in a Christian legal order versus a non-Christian legal order; and competing versions of what should have been the same legal provision, but whose sameness had fallen victim to the inefficiencies of the technology of knowledge production and knowledge transmission. One type of nonuniformity they could not endure without ceasing to exist as a community, the other type was a nuisance which the citation law in its way tried to solve. In this culture, without a state, with oral sensibilities in the process of becoming literate sensibilities, uniform law might be wished for, but impossible to achieve.

Let me conclude by bringing us back to the introduction of Christianity into the laws and complicating the matter a little bit. Communities do not only bind the living together in the present; they bind the living with the dead who preceded them. Thorgeir's compromise meant change, but it did not mean a break with the past. In fact, his judgment was meant to maintain a community of living and dead. Two jural communities would have severed the community from the unity of their frontier experience; one jural community meant that it was the Icelandic commmunity that would survive, a community that had changed through time to be sure, but one whose roots were in a past that, though pagan, was glorious in the way the Christian present

copies of it. Hence the concern with "restoring things left out," unless this refers to laws left out of Haflidi's version. Also, it is clear that subsequent modifications would not appear in Haflidi's text, but would have to appear in other books. In short, there was not and could not be any one authoritative text.

47. See P. Foote, supra note 38. 
was not. The sagas that celebrated Iceland's heathen past were written by a people who lived some 250 years after the Conversion. They did not consign their ancestors to Hell because they were not Christian. They did not moralize tediously about the benighted life their ancestors led without the light of the new law. After all, even a committed Christian would have to see that it was pagans who freely agreed to the new order. It was not rammed down their throats. Even though, to be sure, the Norwegian king could make life miserable for them, he was still a long way across a stormy North Atlantic ocean. In the end, they led the new faith into their law according to their old procedures. If in the views of the new orthodoxy the pagans were benighted, they surely could see very well in the dark, even by the new standards.

***

A story is told about a seventh-century Frisian king named Ratbod $^{48}$ who, on the verge of succumbing to the arguments of a Christian missionary, queried a little more precisely about what he was being promised about Heaven and Hell. He wondered where precisely his ancestors would be. And when informed that they were among the unfortunate in Hell, he refused conversion on the grounds that it would be cowardly to desert his kin. Thorgeir did not quite have Ratbod's grand heroic manner, ${ }^{49}$ but no less than Ratbod he was concerned to bind the past to the present. Thorgeir's was a practical sensibility. Faiths may change with the fashion and so too individual

48. See G. Coulton, Medieval Panorama 37 (1938).

49. Thirteenth-century saga authors depicted people equally tough minded about the old order as about the new. They knew or could imagine the possibility of questioning whether God or gods even cared to care about the affairs of mankind or to intervene in this world. Some of them appeared entirely capable of thinking that the heavens were empty. Consider two brief vignettes. At the moment people at the Law Rock were announcing themselves out of law with each other a man came running in frantically announcing the eruption of a volcano not more than a day's ride from the Allthing, which itself was situated on a lavafield. Says the saga: ings."

The heathens said, "It is hardly surprising that the gods are angry with our proceed-

Then Snorri the chieftain said: "And just what were the gods angry at when this lavafield we are standing on was molten?"

Kristni saga, supra note 12, at ch. 11 (author's translation). Some two hundred years later Sighvat and Arnor were attacking the bishop for whom, obviously, they entertained no liking. Arnor then discussed with Sighvat how good it felt to have the bishop surrounded:

"I was very sick this summer, but when word came to me from the Reykjadalers that they needed help [to attack the bishop] my illness left me so that I feel just fine."

"You will no doubt consider that a miracle," said Sighvat.

"I call such things coincidences, not miracles," said Amor.

Íslendinga saga, ch. 37, in 1 SturLuNGa SAGa 229 (Jón Jóhannesson, Magnús Finnbogason \& Kristján Eldjám eds. 1946) (author's translation). I do not want to make too much of these passages, but they do indicate that in the so-called Christian middle ages, some Icelanders were more than capable of entertaining the possibility of nonorthodox beliefs. People who used the language of miraclemaking a little too loosely could be ridiculed, as could the vanity of those who thought themselves important enough for the Heavens to act in their affairs. 
laws change to accommodate such fashions, but the Law, "our law," bound all previous particular states of the law - pagan past to Christian present - into one single jural community. 